\title{
Front Matter: Volume 11332
}

, "Front Matter: Volume 11332," Proc. SPIE 11332, International Conference on Quantum, Nonlinear, and Nanophotonics 2019 (ICQNN 2019), 1133201 (30 December 2019); doi: 10.1117/12.2565519

SDIE Event: International Conference on Quantum, Nonlinear, and Nanophotonics 2019 (ICQNN 2019), 2019, Sofia, Bulgaria 


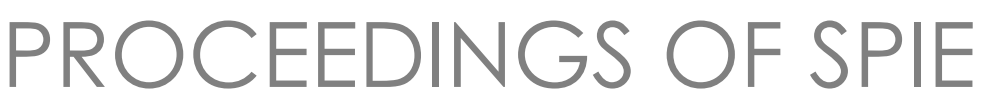

\title{
International Conference on Quantum, Nonlinear, and Nanophotonics 2019 (ICQNN 2019)
}

\author{
Alexander A. Dreischuh \\ Tony Spassov \\ Isabelle Staude \\ Dragomir N. Neshev \\ Editors
}

\section{2-5 September 2019 \\ Sofia, Bulgaria}

Organized by

Sofia University St. Kliment Ohridski (Bulgaria)

The Australian National University (Australia)

Friedrich-Schiller-Universität Jena (Germany)

Sponsored by

Office of Naval Research Global

Sofia University St. Kliment Ohridski (Bulgaria)

Published by

SPIE 
The papers in this volume were part of the technical conference cited on the cover and title page. Papers were selected and subject to review by the editors and conference program committee. Some conference presentations may not be available for publication. Additional papers and presentation recordings may be available online in the SPIE Digital Library at SPIEDigitalLibrary.org.

The papers reflect the work and thoughts of the authors and are published herein as submitted. The publisher is not responsible for the validity of the information or for any outcomes resulting from reliance thereon.

Please use the following format to cite material from these proceedings:

Author(s), "Title of Paper," in International Conference on Quantum, Nonlinear, and Nanophotonics 2019 (ICQNN 2019), edited by Alexander A. Dreischuh, Tony Spassov, Isabelle Staude, Dragomir N. Neshev, Proceedings of SPIE Vol. 11332 (SPIE, Bellingham, WA, 2019) Seven-digit Article CID Number.

ISSN: 0277-786X

ISSN: 1996-756X (electronic)

ISBN: 9781510634312

ISBN: 9781510634329 (electronic)

Published by

SPIE

P.O. Box 10, Bellingham, Washington 98227-0010 USA

Telephone +1 3606763290 (Pacific Time) · Fax +1 3606471445

SPIE.org

Copyright (c) 2019, Society of Photo-Optical Instrumentation Engineers.

Copying of material in this book for internal or personal use, or for the internal or personal use of specific clients, beyond the fair use provisions granted by the U.S. Copyright Law is authorized by SPIE subject to payment of copying fees. The Transactional Reporting Service base fee for this volume is $\$ 21.00$ per article (or portion thereof), which should be paid directly to the Copyright Clearance Center (CCC), 222 Rosewood Drive, Danvers, MA 01923. Payment may also be made electronically through CCC Online at copyright.com. Other copying for republication, resale, advertising or promotion, or any form of systematic or multiple reproduction of any material in this book is prohibited except with permission in writing from the publisher. The CCC fee code is $0277-$ $786 \mathrm{X} / 19 / \$ 21.00$.

Printed in the United States of America by Curran Associates, Inc., under license from SPIE.

Publication of record for individual papers is online in the SPIE Digital Library.

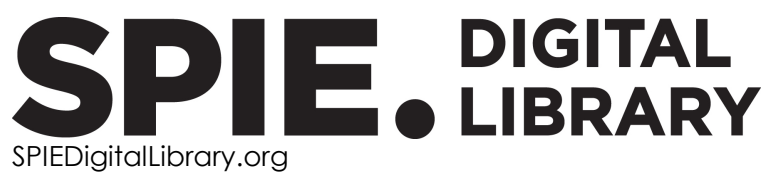

Paper Numbering: Proceedings of SPIE follow an e-First publication model. A unique citation identifier (CID) number is assigned to each article at the time of publication. Utilization of CIDs allows articles to be fully citable as soon as they are published online, and connects the same identifier to all online and print versions of the publication. SPIE uses a seven-digit CID article numbering system structured as follows:

- The first five digits correspond to the SPIE volume number.

- The last two digits indicate publication order within the volume using a Base 36 numbering system employing both numerals and letters. These two-number sets start with $00,01,02,03,04$, 05, 06, 07, 08, 09, 0A, OB ... 0Z, followed by 10-1Z, 20-2Z, etc. The CID Number appears on each page of the manuscript. 


\title{
Contents
}

\author{
$\checkmark \quad$ Authors \\ vii Conference Committee \\ ix Introduction
}

METASURFACES

1133202 Sensing through the optical radiation pattern in dielectric metastructures (Invited Paper) [11332-20]

1133203 Microwave characteristics of thin $\mathrm{Al}_{2} \mathrm{O}_{3}$ membranes as metasamples for optical applications (Invited Paper) [1 1332-4]

\section{NANOMATERIALS}

1133204 Nanocomposite of polymer liquid crystal/single wall carbon nanotubes: isothermal and nonisothermal phase kinetics (Invited Paper) [11332-3]

1133205 Formation of stable and horse head-like shape platinum nanoparticles at the air/water interface (Invited Paper) [11332-10]

1133206 Synthesis and catalytic properties of nanoporous Pd-based alloys: chemical vs. electrochemical de-alloying of Pd-Ni-Si glasses [11332-14]

1133207 Colorimetric detection of iron(III) based on sensitive and selective plasmonic response of starch-coated silver nanoparticles [11332-17]

1133208 Laser beam reflection by nano-designed two-layer nanostructured carbonic material formed in transparent hydrocarbon polymer by ion implantation [1 1332-1]

1133209 Constrained droplet eigenfrequency approach in nanodroplets research [11332-5]

\section{NANOTECHNOLOGY}

11332 OA Laser-induced break down spectroscopy for quantitative analysis of electrolytes ( $\mathrm{Na}, \mathrm{K}, \mathrm{Ca}$, $\mathbf{M g}$ ) in human blood serum (Invited Paper) [11332-7]

$11332 \mathrm{OB} \quad$ A novel construction of Z-scheme $\mathrm{CuO} / \mathrm{g}-\mathrm{C}_{3} \mathrm{~N}_{4}$ heterojunction for visible-light-driven photocatalysis in natural seawater (Invited Paper) [1 1332-8] 
11332 OC Preparation and optical properties of functionalized hydrophobic aerogel granules (Invited Paper) [1 1332-9]

$11332 \mathrm{OD} \quad$ Synthesis and characterization of $\mathrm{As}(\mathrm{V})$-imprinted smart polymer gel for selective adsorption of $\mathrm{As}(\mathrm{V})$ ions [1 1332-15]

11332 OE Viability of zone melting on a micro scale using a focused electron beam (Invited Paper) [11332-19]

\section{PLASMONICS}

$11332 \mathrm{OF} \quad$ An ellipsometrical study of SPR of ferritin on gold surface [11332-6]

11332 OG Plasmonic nanowires embedded in electrospun PVA nanofibers (Invited Paper) [11332-12]

NONLINEAR OPTICS

$11332 \mathrm{OH} \quad$ Four-photon parametric mixing in $\mathrm{CW}$ and pulse regimes in single mode optical fibers [11332-13]

BEAM SHAPING

11332 ol Longitudinal optical force of laser pulses in continuous media (Invited Paper) [11332-16]

$113320 \mathrm{~J}$ Multi-spot focal pattern formation and beam reshaping by mixing square-shaped and hexagonal vortex lattices [11332-18]

11332 OK Transformation of a circularly obstructed Bessel beam by a fork-shaped grating [1 1332-2] 


\section{Authors}

Numbers in the index correspond to the last two digits of the seven-digit citation identifier (CID) article numbering system used in Proceedings of SPIE. The first five digits reflect the volume number. Base 36 numbering is employed for the last two digits and indicates the order of articles within the volume. Numbers start with 00, 01, 02, 03, 04, 05, 06, 07, 08, 09, OA, OB...0Z, followed by 10-1Z, 20-2Z, etc.

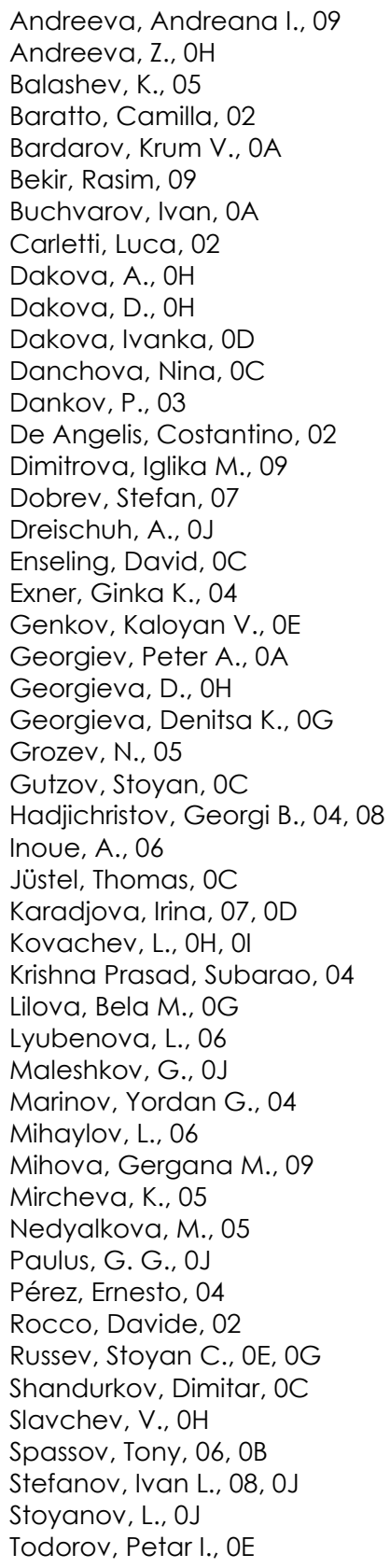


Proc. of SPIE Vol. 11332 1133201-6 Downloaded From: https://www.spiedigitallibrary.org/conference-proceedings-of-spie on 26 Apr 2023
Terms of Use: https://www.spiedigitallibrary.org/terms-of-use 


\title{
Conference Committee
}

\author{
Conference Chairs
}

Alexander A. Dreischuh, Sofia University St. Kliment Ohridski (Bulgaria)

Tony Spassov, Sofia University St. Kliment Ohridski (Bulgaria)

Isabelle Staude, Friedrich-Schiller-Universität Jena (Germany)

Dragomir N. Neshev, The Australian National University (Australia)

Program Committee

Dragomir N. Neshev, The Australian National University (Australia)

Isabelle Staude, Friedrich-Schiller-Universität Jena (Germany)

Tony Spassov, Sofia University St. Kliment Ohridski (Bulgaria)

Alexander A. Dreischuh, Sofia University St. Kliment Ohridski (Bulgaria)

\section{Session Chairs}

Igal Brener, Sandia National Laboratories (United States) and Center for Integrated Nanotechnologies (United States)

Roberto Morandotti, Institut National de la Recherche Scientifique

(Canada)

Dragomir N. Neshev, The Australian National University (Australia)

Alexander A. Dreischuh, Sofia University St. Kliment Ohridski (Bulgaria)

Gerhard Paulus, Friedrich-Schiller-Universität Jena (Germany)

Andrey Sukhorukov, The Australian National University (Australia)

Costantino De Angelis, University of Brescia (Italy)

Isabelle Staude, Friedrich-Schiller-Universität Jena (Germany)

Andon Rangelov, Sofia University St. Kliment Ohridski (Bulgaria)

Tony Spassov, Sofia University St. Kliment Ohridski (Bulgaria) 
Proc. of SPIE Vol. 11332 1133201-8 Downloaded From: https://www.spiedigitallibrary.org/conference-proceedings-of-spie on 26 Apr 2023
Terms of Use: https://www.spiedigitallibrary.org/terms-of-use 


\section{Introduction}

The International Conference on Quantum, Nonlinear and Nanophotonics (ICQNN'2019) and the satellite symposium of Nanomaterials and Nanotechnologies (SNN'2019) were held from 2-5 September 2019 in Sofia, Bulgaria. The conference scope covered the investigation of basic physical phenomena of light interaction with different natural materials and artificial structures, as well as the technological applications of such phenomena, novel devices, instruments, and methods. The topics included quantum and nonlinear optics, nano-optics, and meta-optics. Leading scientists delivered three plenary and 22 invited talks on the newest development in these research areas. The conference and the symposium served as a meeting place for 62 researchers from 15 countries (Australia, Canada, China, France, Germany, Israel, Italy, Kazakhstan, Macedonia, Serbia, Spain, Switzerland, the Netherlands, United States, and Bulgaria).

The host organization was Sofia University St. Kliment Ohridski, the first higher education institution in Bulgaria. The first step towards its foundation was in 1887. For 130 years Sofia University has been the national foremost center for university education and research. Today it is the largest university in Bulgaria with more than 120 degree-programs offered by 16 faculties.

The conference and the symposium were jointly organized by Friedrich-SchillerUniversität Jena (Institut für Angewandte Physik, and Institut für Optik und Quantenelektronik, Jena, Germany), The Australian National University (ANU College of Science, Canberra, Australia), and Sofia University St. Kliment Ohridski (Faculty of Physics and Faculty of Chemistry and Pharmacy, Sofia, Bulgaria). The organizers acknowledge the financial support from the Office of Naval Research Global.

Alexander A. Dreischuh Tony Spassov Isabelle Staude Dragomir N. Neshev 
Proc. of SPIE Vol. 11332 1133201-10 Downloaded From: https://www.spiedigitallibrary.org/conference-proceedings-of-spie on 26 Apr 2023
Terms of Use: https://www.spiedigitallibrary.org/terms-of-use 